\title{
Activity Based Student's Performance Measure Using Moodle Log Files
}

\author{
K K Singh, Uday Kumar, Kumar Anurupam
}

\begin{abstract}
Blended learning, a thoughtful integration of face-to-face and online learning aims at: improving students' learning outcome and providing personalized learning experience through eLearning technologies, such as Moodle. To ascertain the benefits of blended learning, a study is performed on 150 students of the blended course offered at RGUKT Nuzvid through the Moodle Platform.
\end{abstract}

The activity log files generated by the Moodle are collected at the end of the course. A set of the metrics are derived from the log files and actual grade of the corresponding students are obtained from final exam result. The metrics obtained from the log files are mapped to the final grade using a classification technique (Decision Tree Classification) and the hidden rules are generated to show the relation between the metrics and the final Grade. The results show the significance of the model.

Index Terms - Blended learning, Moodle platform, activity $\log$ files, students performance, decision tree classification

\section{INTRODUCTION}

Blended learning is a combination integration of face-to-face and online learning which provides personalized learning experience through eLearning technologies, such as Moodle. Studies show that blended learning model helps students who are struggling to catch up, enriching the learning content and improving students' engagement. The learning platform provides teachers also a scope to study the behaviours of the students based upon their activities captured during the course. In this work the activity log files generated by the Moodle are collected at the end of the course. A set of the metrics are derived from the log files and actual grade of the corresponding students are obtained from final exam result. The metrics obtained from the log files are mapped to the final grade using a classification technique (Decision Tree Classification) and the hidden rules are generated to show the relation between the metrics and the final Grade.

The log files included many attributes including time span and activity types. The sample data of the activity log file is tabulated in Table-1.

Manuscript revised on July 9, 2019 and published on August 10, 2019 K K Singh, Department of CSE, RGUKT Nuzvid, India. Email ID: krishnasingh@rguktn.ac.in

Uday Kumar, Department of CSE, RGUKT Nuzvid, India. Email ID: uday@rguktn.ac.in

Kumar Anurupam Department of CSE, RGUKT Nuzvid, India. Email ID: kumaranurupam@rguktn.ac.in
A set of new metrics are derived from the log files as mentioned below.

Mean Time Between Access (MTBA), Total Mean Time Between Access (TMTBA), Total Logged-in Time (TLT), Sum of Activity Rating (SAR). Final grade in the subject is collected from the semester results.

\section{Table-1: Sample data of activity file of Moodle}

\begin{tabular}{|c|c|c|c|c|c|c|c|c|}
\hline Time & $\begin{array}{l}\text { User full } \\
\text { name }\end{array}$ & $\begin{array}{l}\text { Affected } \\
\text { user }\end{array}$ & $\begin{array}{l}\text { Event } \\
\text { context }\end{array}$ & $\begin{array}{l}\text { Compone } \\
\text { nt }\end{array}$ & $\begin{array}{l}\text { Event } \\
\text { name }\end{array}$ & Description & $\begin{array}{l}\text { Origi } \\
\text { n }\end{array}$ & IP address \\
\hline $\begin{array}{l}\text { 1/02/18, } \\
00: 04\end{array}$ & \begin{tabular}{|l|} 
SHAIK \\
MOHA \\
MMED \\
TASLEE \\
MA \\
Nuzvid
\end{tabular} & & $\begin{array}{l}\text { Assignmen } \\
\mathrm{t}: \\
\text { Assignmen } \\
\mathrm{t}-1 \text { (15 } \\
\text { jan-1 Feb } \\
2018)\end{array}$ & $\begin{array}{l}\text { Assignme } \\
\text { nt }\end{array}$ & $\begin{array}{l}\text { The status } \\
\text { of the } \\
\text { submissio } \\
n \text { has been } \\
\text { viewed. }\end{array}$ & \begin{tabular}{|l|} 
The user with id \\
'294' has viewed the \\
submission status \\
page for the \\
assignment, course \\
module id '1605'.
\end{tabular} & web & $\begin{array}{l}192.168 .155 \\
102\end{array}$ \\
\hline $\begin{array}{l}\text { 1/02/18, } \\
00: 15\end{array}$ & \begin{tabular}{|l|} 
KADAM \\
ANCHI \\
RAVI \\
KUMAR \\
Nuzvid
\end{tabular} & \begin{tabular}{|l} 
KADAMA \\
NCHI \\
RAVI \\
KUMAR \\
Nuzvid
\end{tabular} & $\begin{array}{l}\text { Assignmen } \\
\text { t: } \\
\text { Assignmen } \\
\text { t-1 (15 } \\
\text { jan-1 Feb } \\
\text { 2018) } \\
\end{array}$ & $\begin{array}{l}\text { Assignme } \\
\text { nt }\end{array}$ & $\begin{array}{l}\text { Submissio } \\
\mathrm{n} \text { form } \\
\text { viewed. }\end{array}$ & \begin{tabular}{|l|} 
The user with id \\
'250' viewed their \\
submission for the \\
assignment, course \\
module id '1605'.
\end{tabular} & web & $\begin{array}{l}192.168 .58 .2 \\
49\end{array}$ \\
\hline $\begin{array}{l}\text { 1/02/18, } \\
00: 16\end{array}$ & \begin{tabular}{|l|} 
KADAM \\
ANCHI \\
RAVI \\
KUMAR \\
Nuzvid
\end{tabular} & $\begin{array}{l}\text { KADAMA } \\
\text { NCHI } \\
\text { RAVI } \\
\text { KUMAR } \\
\text { Nuzvid }\end{array}$ & $\begin{array}{l}\text { Assignmen } \\
\mathrm{t}: \\
\text { Assignmen } \\
\mathrm{t}-1 \text { (15 } \\
\text { jan-1 Feb } \\
2018)\end{array}$ & $\begin{array}{l}\text { Assignme } \\
\text { nt }\end{array}$ & $\begin{array}{l}\text { Submissio } \\
\text { n form } \\
\text { viewed. }\end{array}$ & \begin{tabular}{|l|} 
The user with id \\
'250' viewed their \\
submission for the \\
assignment, course \\
module id '1605'.
\end{tabular} & web & $\begin{array}{l}192.168 .58 .2 \\
49\end{array}$ \\
\hline $\begin{array}{l}\text { 1/02/18, } \\
00: 16\end{array}$ & \begin{tabular}{|l|} 
KADAM \\
ANCHI \\
RAVI \\
KUMAR \\
Nuzvid
\end{tabular} & & \begin{tabular}{|l|} 
Assignmen \\
$\mathrm{t}:$ \\
Assignmen \\
$\mathrm{t}-1(15$ \\
jan-1 Feb \\
2018)
\end{tabular} & $\begin{array}{l}\text { Assignme } \\
\text { nt }\end{array}$ & $\begin{array}{l}\text { The status } \\
\text { of the } \\
\text { submissio } \\
\mathrm{n} \text { has been } \\
\text { viewed. }\end{array}$ & \begin{tabular}{|l|} 
The user with id \\
'250' has viewed the \\
submission status \\
page for the \\
assignment, course \\
module id '1605'.
\end{tabular} & web & $\begin{array}{l}192.168 .58 .2 \\
49\end{array}$ \\
\hline
\end{tabular}

The subsequent sections are as follows; the section-2 presents the related work in the regard, the section-3 describes the stepwise procedure, modelling and the result, section- 4 concludes the work

\section{RELATED WORKS}

Some of the recent works which show the positive impacts of using blended learning using LMS (Learning management system) like Moodle are cited here.

A meta-analysis is conducted in [1] to perform a statistical synthesis of studies contrasting student performance in blended learning (BL) conditions with traditional classroom instruction. The finding confirms that blended learning (BL) is significantly associated with greater learning performance of STEM (Science, Technology, Engineering and Math)-disciplined students than with traditional classroom practice.

A retrospective design in [2] was used to review the students' VLE (virtual learning environment) and their performance on the summative assessments of the two concurrent academic cohorts. Data were analyzed descriptively and statistically for 
significance. There was a significant difference between the two cohort's accesses to the VLE $(p \leq 0.002)$ indicating higher habituation to blended learning in the second cohort, who had more exposure to e-learning due to their second year of using VLE.

The paper [3] presents a study conducted and analysed the relationship between the proportion of the course implemented in the Moodle e-learning platform and students' performance on one hand and their satisfaction on the other. The empirical findings reveal a positive correlation for the elements e.g. students on average receive better grades and require fewer admissions to pass the exam.

\section{PROCEDURE AND COMPUTATION RESULT}

The step wise procedure to model the problem is described below.

Step-1: The log file Table is collected from the Moodle which is already sorted w.r.t. Time to access; the same is further sorted w.r.t. Name of the user.

Step-2: The "time" attribute is converted into second.

Step-3: Each activity (event) is assigned a rank based on expert knowledge; e.g. actively like 'view' is awarded a rank 1 , creating an activity is awarded a rank 2 , and submitting or uploading an activity is awarded a rank 3. It is tabulated in Table-2.

Step-4: A set of new attributes are derived corresponding to each user, i.e. the data is aggregated with respect to user (the student).

- Mean Time Between Access (MTBA), Total Time Between Access(TTBA), Total Logged-in Time(TLT), and Sum of Activity Rating (SAR)

Table-2: The event name provided in the Moodle platform and the rating assigned

\begin{tabular}{|c|c|c|c|c|c|}
\hline Event name & Rating & Event name & Rating & Event name & Rating \\
\hline Course viewed & 1 & $\begin{array}{l}\text { Submission } \\
\text { created. }\end{array}$ & 2 & $\begin{array}{c}\text { A submission } \\
\text { submitted. }\end{array}$ & 3 \\
\hline $\begin{array}{l}\text { Survey response } \\
\text { submitted }\end{array}$ & 1 & Discussion created & 2 & \begin{tabular}{|} 
An online text \\
/file uploaded.
\end{tabular} & 3 \\
\hline $\begin{array}{l}\text { User profile } \\
\text { viewed }\end{array}$ & 1 & $\begin{array}{l}\text { Quiz attempt } \\
\text { started }\end{array}$ & 2 & $\begin{array}{c}\text { Quiz attempt } \\
\text { submitted }\end{array}$ & 3 \\
\hline Discussion viewed & 1 & User graded & 2 & & \\
\hline $\begin{array}{l}\text { Grade user report } \\
\text { viewed }\end{array}$ & 1 & $\begin{array}{l}\text { Course activity } \\
\text { completion } \\
\text { updated }\end{array}$ & 2 & & \\
\hline User list viewed & 1 & Post created & 2 & & \\
\hline $\begin{array}{l}\text { Submission form } \\
\text { viewed. }\end{array}$ & 1 & $\begin{array}{l}\text { Discussion } \\
\text { subscription } \\
\text { created }\end{array}$ & 2 & & \\
\hline $\begin{array}{l}\text { Quiz attempt } \\
\text { viewed }\end{array}$ & 1 & $\begin{array}{l}\text { Some content } \\
\text { posted. }\end{array}$ & 2 & & \\
\hline
\end{tabular}

The sample data of the derived attributes and the grade of the student are shown in the Table-3.
Table-3: A sample data of the derived attributes and the Grade of the student

\begin{tabular}{|l|l|l|l|l|}
\hline $\begin{array}{l}\text { MTB } \\
\text { A }\end{array}$ & $\begin{array}{l}\text { TTB } \\
\text { A }\end{array}$ & $\begin{array}{l}\text { AA } \\
\text { R }\end{array}$ & $\begin{array}{l}\text { TL } \\
\text { Grad } \\
\text { e }\end{array}$ \\
\hline 11.14 & 78 & 7 & 3 & C \\
\hline 18.95 & 300 & 26 & 13 & C \\
\hline 19.25 & 462 & 34 & 14 & A \\
\hline 37.38 & 299 & 8 & 5 & B \\
\hline 37.84 & 1400 & 6 & 1 & D \\
\hline 44 & 88 & 2 & 3 & C \\
\hline 44.4 & 666 & 21 & 7 & B \\
\hline 86.57 & 606 & 7 & 2 & D \\
\hline 104.49 & 4493 & 43 & 16 & A \\
\hline
\end{tabular}

The distribution of each of the attribute; MTBA, TTBA, SAR, and TLT given in the Table-3, corresponding to each the Grade (A, B, C, and D; the Target variable) are plotted to see their interdependency and are shown in the Figure-1, Figure-2, Figure-3, and Figure-4 respectively.

\section{Distribution of Mean Time between Access vs Grade of the students}

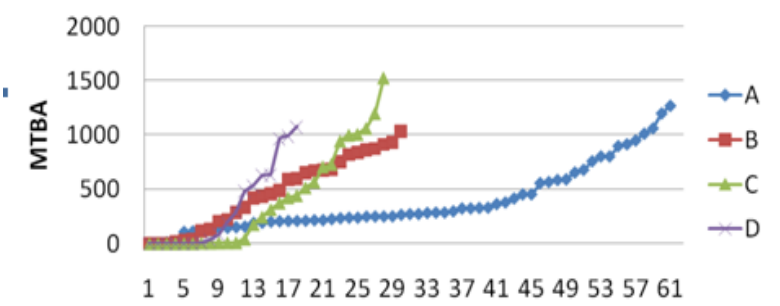

Figure-1: Distribution of MTBA corresponding to each of the Grade

\section{Distribution of Total Time Between Access vs Grade of the students}

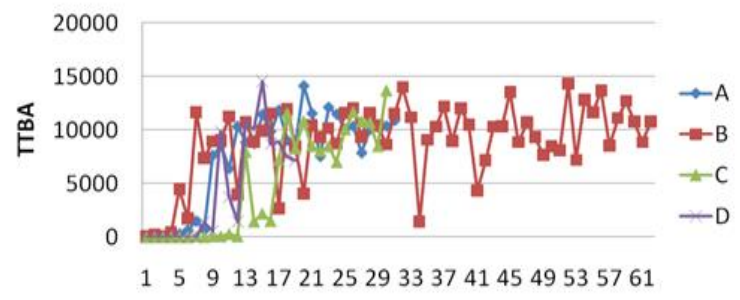

Figure-2: Distribution of TTBA corresponding to each of the Grade 
Distribution of Sum of Activity Rating vs Grade of the students

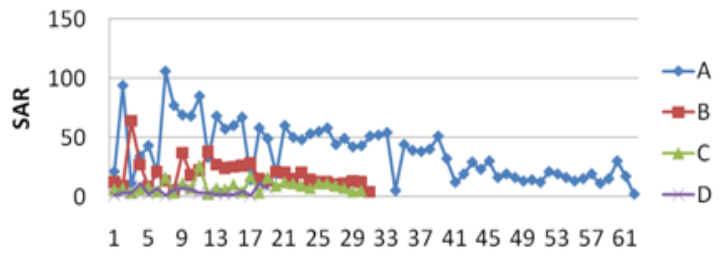

Figure-3: Distribution Of SAR Corresponding To Each Of The Grade

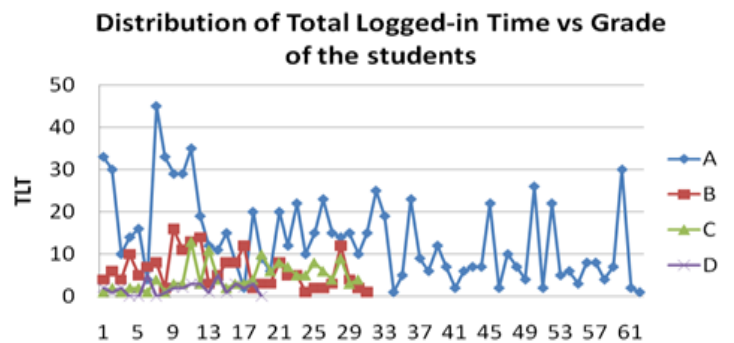

Figure-4: Distribution of SAR corresponding to each of the Grade

In the Figure-1, Figure-2, Figure-3, and Figure-4, it is observed that MTBA and TTBA are more random in nature with respect to the Grades.

The Decision tree induction method is applied on the dataset given in the Table-3, and the performance metrics; accuracy, precision, recall, and f-measure are obtained from the confusion matrix of the model. The purpose of emphasizing decision tree as classification method is to extract the rule and to get more tangible relation between input attributes and the target variable (grade). The decision tree of the model is shown in the Figure- 5 below.

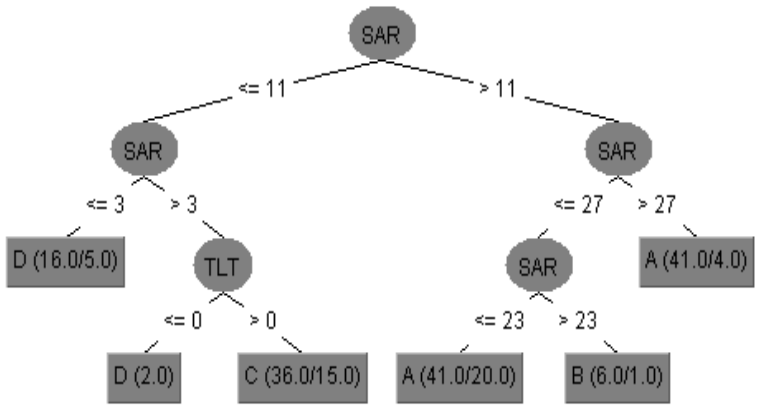

Figure-5: Decision tree for the data set in Table-3

By observing the tree, it is observed that the Mean Time Between Access (MTBA), and Total Time Between Access (TTBA) are not participating in the decision. The reason is that they appear to be random; i.e. their distributions with respect to the corresponding grades are not distinguishable, as shown in figure-1 and in figure-2. Sum of Activity Rating (SAR) appeared the most deciding attribute in the decision tree.
Every Path from root node to leaf node of the Tree is a rule, as shown the Figure-6.

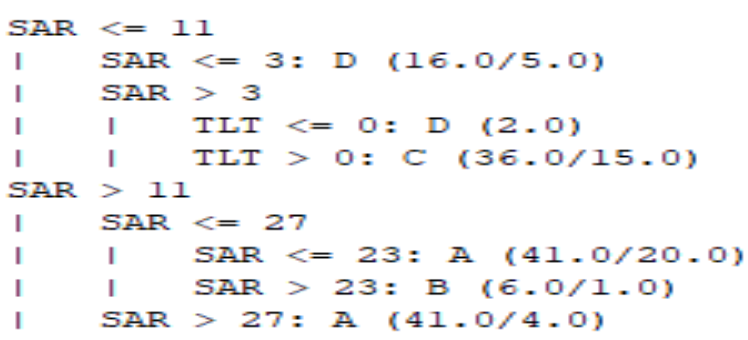

Figure-6: Rules corresponding to the decision tree

The model is validated with $\mathrm{K}$-fold cross validation approach. The Performance measures are tabulated below. Accuracy $=61.9718 \%$

TP Rate Precision Recall F-Measure ROC Area

$\begin{array}{lllll}0.62 & 0.592 & 0.62 & 0.6 & 0.78\end{array}$

\section{CONCLUSION}

It is observed that the students' performance in term of final grade obtained in the course has significant relation with the activity they perform and how much time they spend on Moodle platform during the course.

It is observed that students having higher grade have higher Sum of Activity Rating (SAR) and the Total Logged-in Time (TLT). It is also observed that the Mean Time Between Access (MTBA), and Total Time Between Access (TTBA) are not participating in the decision as their distributions are random in nature w.r.t grades. Though the Model accuracy obtained is $62 \%$, it may be improved further by collecting more samples. The results of our future work will provide a greater insight into the relationships we studied in this work

\section{REFERENCES}

[1] Olitsky, Neal H., and Sarah B. Cosgrove. "The Effect of Blended Courses on Student Learning: Evidence from Introductory Economics Courses.", International Review of Economics Education, pp.15-17, 2014.

[2] Paula Barnard Ashton, Lindsay Kock, Alan Rothberg “ The influence of blended learning on student performance in an undergraduate occupational therapy curriculum", School of Therapeutic Sciences, Faculty of Health Sciences, University of the Witwatersr and South African Journal of Occupational Therapy - Volume 44, Number 1, April 2014

[3] Lan Umek, Aleksander Aristovnik, Nina Tomaževic \& Damijana Keržic, University of Ljubljana, SLOVENIA, "Analysis of Selected Aspects of Students' Performance and Satisfaction in a Moodle-Based E-Learning System Environment", Eurasia Journal of Mathematics, Science \& Technology Education, 11(6), pp.1495-1505, 2015 